\title{
Heavy metal content and molecular species identification in canned tuna: Insights into human food safety
}

\author{
ANNA MARIA PAPPALARDO $^{1 *}$, CHIARA COPAT $^{2 *}$, VENERA FERRITO $^{1}$, \\ ALFINA GRASSO $^{2}$ and MARGHERITA FERRANTE ${ }^{2}$ \\ ${ }^{1}$ Department of Biological, Geological and Environmental Sciences, University of Catania, I-95124 Catania; \\ ${ }^{2}$ Department of Medical, Surgical Sciences and Advanced Technologies 'G.F. Ingrassia', \\ Hygiene and Public Health, University of Catania, I-95123 Catania, Italy
}

Received December 30, 2016; Accepted February 20, 2017

DOI: $10.3892 / \mathrm{mmr} .2017 .6376$

\begin{abstract}
Canned tuna in olive oil and in brine of the most popular brands sold in Italian markets were analyzed to verify the authentication of transformed products, with the aim to unveil commercial frauds due to the substitutions of high value species with species of low commercial value, and to assess the health risk of consumers related to cadmium $(\mathrm{Cd})$, lead $(\mathrm{Pb})$ and mercury $(\mathrm{Hg})$ contents. Species authentication was evaluated with amplification of COI DNA barcode and confirmed the declared species. Among tested metals, $\mathrm{Hg}$ had the highest concentrations, followed by $\mathrm{Cd}$ and $\mathrm{Pb}$. None of the tested samples surpassed the European regulatory limits no. 1881/2006 fixed for $\mathrm{Hg}$ and $\mathrm{Pb}$, whereas one batch of canned tuna in olive oil exceeded standard for Cd. Risk for human health was evaluated by the metals daily intake and target hazard quotient (THQ). As a result, $\mathrm{Cd}$ and $\mathrm{Pb}$ did not exceed the toxicological reference values established by World Health Organization (WHO) and the Environmental Protection Agency (EPA). Conversely, Hg content suggests a consumption no more than once a week and a continuous surveillance of this fishery products for consumer protection.
\end{abstract}

\section{Introduction}

Bioaccumulation and biomagnification of pollutants are considered the major threats to human and ecosystem health (1-4). In particular, heavy metals can be readily assimilated and bioaccumulated in organisms inducing a potential risk to human health by consuming contaminated food (5).

Correspondence to: Dr Chiara Copat, Department of Medical, Surgical Sciences and Advanced Technologies 'G.F. Ingrassia', Hygiene and Public Health, University of Catania, Via Santa Sofia 87, I-95123 Catania, Italy

E-mail: ccopat@unict.it

*Contributed equally

Key words: canned tuna, DNA barcode, heavy metals, daily intake, target hazard quotient
Since 2002, food safety is a major concern of the European Union (EU) member states and protecting consumers' health with independent scientific advice on the food chain is the main objective of the EFSA strategy 2020 (6). For this reason, studies dealing with risks and benefits of seafood consumption related to the presence of toxic chemicals in fish, are growing (7-11).

Due to their place in the food chain, the large predatory fish, such as swordfish and tuna, are considered the main source of human exposure to metals. A large part of the scientific literature, dealing with health risk linked to the consumption of fish in the world, endorses this statement focusing, for example, on levels of toxic metals in fresh and canned tuna (12-15). In Europe, limits for contaminants in foodstuffs are established by the Commission Regulation (EC) no. 1881/2006 of December 19, 2006, setting maximum levels for lead $(\mathrm{Pb})$, cadmium $(\mathrm{Cd})$, and mercury $(\mathrm{Hg})(\mathrm{Pb}$ in muscle meat of fish must not exceed $0.30 \mathrm{mg} / \mathrm{kg}$ wet weight (w.w.); $\mathrm{Cd}$ and $\mathrm{Hg}$ must not exceed 0.10 and $1.0 \mathrm{mg} / \mathrm{kg}$ w.w., respectively, in Thunnus species, Euthynnus species and Katsuwonus pelamis).

Interspecific differences in metal concentrations exist due to the trophic level occupied by the fish, the region it inhabits, the size and the age of the fish. For example Thunnus albacares (Yellowfin tuna) from Taiwan contains level of heavy metals in the muscle highest than those detected in the same species from New Jersey; T. albacares from Reunion island, in the Western Indian Ocean, contains level of heavy metals highest than those detected in Katsuwonis pelamis from the same region (16). For these reasons, the EFSA Scientific Committee recommended to each country to consider its own pattern of fish consumption, especially the species of fish consumed, and carefully assess the risk of exceeding the tolerable daily intake (TWI), in particular, of methylmercury (17). Because of the expansion of the fish global market and the citizen awareness of the risks, a high and growing interest in the origin of seafood products has been triggered in consumers, who demand for food quality and safety assurance. In this context and because of the alarming levels of seafood mislabeling worldwide detected (18-24), the accurate identification of fish species in transformed products is essential to verify food quality.

The reliability and sensitivity of species authentication through molecular biology techniques is widely acknowledged, 
especially when species lose the diagnostic morphological characters useful to recognize them, due to the industrial processing of food. The DNA barcoding methodology is currently used to identify species and a partial sequence of the mitochondrial gene cytochrome oxidase I (COI) referred to as a barcode sequence, has been widely used for fish species identification in transformed fishery products (25-39). Of note, Lowenstein et al (40) used COI DNA barcode to identify tuna sushi samples analyzed for mercury to more accurately measure the health risk to consumers. Based on consideration above, the aims of the present work are: i) to authenticate tuna species via COI DNA barcode; ii) to evaluate the levels of heavy metals in samples of canned tuna of the most popular brands sold in Italy; iii) to assess which brands could pose a health risk to consumers.

\section{Materials and methods}

Sampling. A total of 5 brands of canned tuna in olive oil (coded from X1 to X5 in the tables) and 5 brands of canned tuna in brine (coded from X6 to X10 in the tables) packaged in metal cans, representing the most popular brands sold in Italy, were purchased from local markets during 2015 and 2016. Sampling was repeated three times to analyze three different batches of the same brand. A total of 30 canned tuna were processed, stored in laboratory at $-80^{\circ} \mathrm{C}$ until analysis.

DNA analysis. For each brand three samples were chosen randomly and processed to investigate the presence of multiple species in the product. The canned tissue samples were washed, at least three times, in Milli-Q water (Q-Gard ${ }^{\circledR} 1$, Merck Millipore, Darmstadt, Germany) and then preserved in $95 \%$ ethanol (J.T. Baker, Deventer, Netherlands). Total genomic DNA was extracted using DNeasy tissue extraction kit (Qiagen) following the manufacturer's protocol. All PCR amplifications were carried out using the primers FishF1 and FishR1 described in Ward et al (35) and following the methodology detailed in Pappalardo and Ferrito (33). Sequences were carefully checked and deposited in GenBank (http://www.ncbi. nlm.nih.gov/genbank/). The chromatograms obtained were edited using BioEdit v7.0.8 (Ibis Biosciences, Carlsbad, CA, USA) (41) to generate a consensus sequence for each specimen. The DNA sequences were aligned using the ClustalX (42) tool in the MEGA v5.0 software (Society for Molecular Biology and Evolution, Oxford, UK) (43). A COI reference library of six tuna species sequences from GenBank (Thunnus albacares, KT211348; Katsuwonus pelamis, KJ968132; Thunnus thynnus, KT352985; Thunnus obesus, KP975908; Thunnus alalunga, KC501691; Euthynnus alletteratus, KJ709729) and 27 sequences from processed samples were used to build a Maximum Likelihood tree in MEGA v 5.0 using Tamura Nei model. Evaluation of statistical confidence in nodes was based on 1,000 non-parametric bootstrap replicates (44). Ambiguous extremities of the sequences were trimmed after alignment.

Heavy metals analysis. Three aliquots of $0.5 \mathrm{~g}$ of each sample were weighted for metals extraction and quantification. As previously described in detail (10), the samples were acid digested in an Ethos TC microwave system (Milestone S.r.l, Bergamo, Italy). A digestion solution was prepared with $6 \mathrm{ml}$ of $65 \%$ nitric

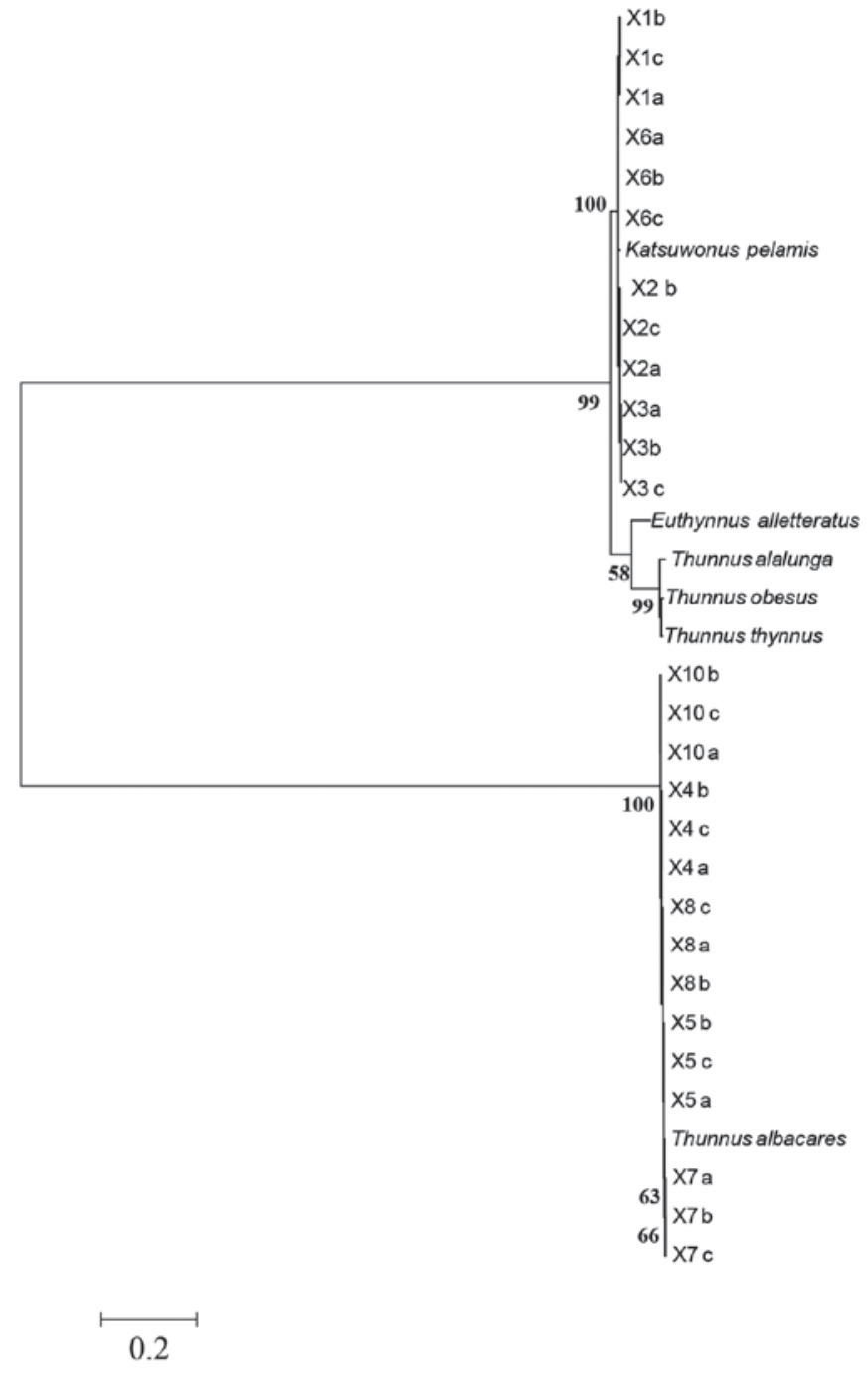

Figure 1. COI ML tree of canned tuna samples (X) and tuna reference bar code sequences. The numbers above the nodes represent bootstrap analysis after 1,000 replicates. a, b and c letters refer to the three samples randomly selected from each canned tuna.

acid $\left(\mathrm{HNO}_{3}\right)($ Carlo Erba, Milan, Italy) and $2 \mathrm{ml}$ of $30 \%$ peroxide hydrogen $\left(\mathrm{H}_{2} \mathrm{O}_{2}\right.$-Carlo Erba) over a $50 \mathrm{~min}$, operation cycle at $200^{\circ} \mathrm{C}$. After the cycle, at a temperature $<25^{\circ} \mathrm{C}$ the vessels were opened and ultra-pure water (Merck Millipore, Bedford, MA, USA) was added to the samples up to $30 \mathrm{ml}$; an ICP-MS Elan-DRC-e (Perkin-Elmer, Norwalk, CT, USA) was used for metal quantification. Standards for the instrument calibration were prepared with mono element certified reference solution ICP Standard (Merck Millipore). Standard reference material Lake Superior fish 1946 NIST (NIST, Gaithersburg, MD, USA) was used to validate analysis. We obtained recoveries of 96.2, 94.1 and $89.4 \%$, respectively, for $\mathrm{Cd}, \mathrm{Pb}$ and $\mathrm{Hg}$ certified values. $\mathrm{Pb}$ reference value was not given in the certificate of analysis, thus we spiked 10 real samples in duplicate with $5 \mu \mathrm{g} / 1$ of each element to validate analysis, and the percentage of recovery ranged was of $110.6 \%$. The method detection limits (MDL) estimated with $3 \sigma$ of the procedure blanks were (mg/ $\mathrm{kg}$ w.w.): $\mathrm{Cd} 0.003, \mathrm{~Pb} 0.001$ and $\mathrm{Hg} 0.002$.

Statistical analysis. Statistical analysis was performed with IBM SPSS 20.0 software (IBM SPSS, Armonk, NY, USA). 
Table I. Samples of canned tuna from Italian supermarkets included in this study.

\begin{tabular}{lllll}
\hline Code & Canned product & Declared species & Identified species & GenBank acc. no. \\
\hline X1 & Tuna in olive oil & Katsuwonus pelamis & Katsuwonus pelamis & KY652762 \\
X2 & Tuna in olive oil & Katsuwonus pelamis & Katsuwonus pelamis & KY652763 \\
X3 & Tuna in olive oil & Katsuwonus pelamis & Katsuwonus pelamis & KY652764 \\
X4 & Tuna in olive oil & Thunnus albacares & Thunnus albacares & KY652765 \\
X5 & Tuna in olive oil & Thunnus albacares & Thunnus albacares & KY652766 \\
X6 & Tuna in brine & Katsuwonus pelamis & Katsuwonus pelamis & KY652767 \\
X7 & Tuna in brine & Thunnus albacares & Thunnus albacares & KY652768 \\
X8 & Tuna in brine & Thunnus albacares & Thunnus albacares & KY652769 \\
X9 & Tuna in brine & Tuna spp. & Not identified & Thunnus albacares \\
X10 & Tuna in brine & Thunnus albacares & KY52770 \\
\hline
\end{tabular}

Mann-Whitney U test for medians comparison between groups, canned tuna in olive oil and in brine, and between declared species, was applied.

Risk assessment for consumers. The daily intake and the risk assessment were calculated according to the equation reported in previous studies (45-47).

$$
\begin{gathered}
\text { EDI }=\text { MS } \times \text { C/BW } \\
\text { THQ }=(\text { EF } \times \text { ED } \times \text { MS } \times \text { C }) /(\text { RfDo } \times \text { BW } \times \text { AT })
\end{gathered}
$$

Where EDI is the estimated daily intake and THQ is the target hazard quotient estimated per meal size (MS=120 g), corresponding to a whole packaged canned tuna. When THQ risk is above 1 , systemic effects may occur, and it means that THQ is higher than the maximum permitted reference dose. The Environmental Protection Agency (EPA) for consumption limits calculation in adult population provides most of the variables as default values of the equations. In particular they are the following: BW is the body weight (adults, $70 \mathrm{~kg}$ ); EF is the exposure frequency, or number of exposure events per year of exposure (365 days/year for people who eat fish seven times a week; 208 days/year for people who eat fish four times a week; 52 days/year for people who eat fish once a week); ED is the exposure duration (adults, 70 years); RfDo is the oral reference dose $(\mu \mathrm{g} / \mathrm{g} /$ day); $\mathrm{AT}$ is the averaging time (it is equal to $\mathrm{EF} \times \mathrm{ED}), \mathrm{C}$ is the metal concentration found in this study (expressed as $\mu \mathrm{g} / \mathrm{kg}$ w.w. in EDI and as $\mu \mathrm{g} / \mathrm{g}$ in THQ).

Values of the RfDo are provided by EPA's Integrated Risk Information System online database. If it was not available, we used the respective metal provisional tolerable daily intake (PTDI) provided by World Health Organization (WHO) for THQ calculation.

\section{Results}

COI DNA barcode. Unambiguously aligned sequences were obtained for 655-659 bp of the COI gene from 30 samples of tuna canned products. The three samples randomly chosen for each brand, yielded sequences belonging to the same species. No insertions, deletions or stop codons were observed. The

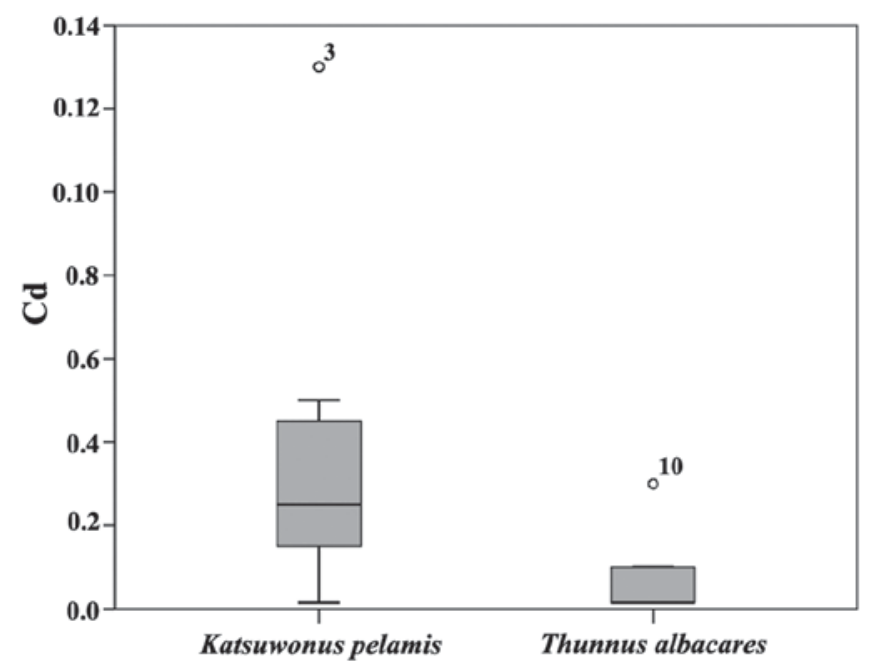

Figure 2. Box Plot of Cd concentrations in Katsuwonus pelamis and Thunnus albacares.

lack of stop codons is consistent with all amplified sequences being functional mitochondrial COI sequences, along with the fact that all amplified sequences were of the same length. This suggests that NUMTs (nuclear DNA sequences originating from mitochondrial DNA sequences) were not sequenced [vertebrate NUMTS are generally smaller than 600 bp (48)].

The ML tree built using the 6 reference sequences and 27 COI sequences of tuna canned samples (Fig. 1), revealed that all sequences from brands labeled as yellowfin tuna clustered with the Thunnus albacares reference sequence; only four COI sequences out of five products labeled as skipjack tuna clustered with the Katsuwonis pelamis reference sequence. One sample out of ten products labeled as tuna yielded no amplification (Table I).

Heavy metals. Ten brands of canned tuna were analyzed to detect concentrations of metals regulated by the EC no. 1881/2006 (Table II). We found mean concentration of Cd of all brands below the law limit of $0.10 \mathrm{mg} / \mathrm{kg} \mathrm{w.w.,} \mathrm{although}$ one batch of the brand 1 in olive oil was over $(0.13 \mathrm{mg} / \mathrm{kg} \mathrm{w.w.})$. Mean concentration of $\mathrm{Pb}$ was always found below the law 
Table II. Mean concentrations and standard deviations (SD) of Cd, $\mathrm{Pb}$ and $\mathrm{Hg}(\mathrm{mg} / \mathrm{Kg}$ wet weight) in canned tuna of different brands.

\begin{tabular}{|c|c|c|c|c|c|c|}
\hline \multirow[b]{2}{*}{ Canned tuna } & \multicolumn{2}{|c|}{$\begin{array}{c}\text { Cd (EU limit: } \\
0.10 \mathrm{mg} / \mathrm{Kg} \text { w.w.) }\end{array}$} & \multicolumn{2}{|c|}{$\begin{array}{c}\mathrm{Pb} \text { (EU limit: } \\
0.30 \mathrm{mg} / \mathrm{Kg} \text { w.w.) }\end{array}$} & \multicolumn{2}{|c|}{$\begin{array}{l}\mathrm{Hg} \text { (EU limit: } \\
1 \mathrm{mg} / \mathrm{Kg} \text { w.w.) }\end{array}$} \\
\hline & Mean & SD & Mean & SD & Mean & SD \\
\hline \multicolumn{7}{|l|}{ Olive oil } \\
\hline $\mathrm{X} 1$ & 0.060 & 0.062 & $<0.001$ & I & 0.240 & 0.320 \\
\hline $\mathrm{X} 2$ & 0.020 & 0.006 & $<0.001$ & 1 & 0.050 & 0.050 \\
\hline $\mathrm{X} 3$ & 0.030 & 0.010 & 0.010 & 0.006 & 0.050 & 0.053 \\
\hline $\mathrm{X} 4$ & 0.010 & 0.015 & 0.010 & 0.006 & 0.170 & 0.170 \\
\hline X5 & 0.010 & 0.006 & $<0.001$ & I & 0.260 & 0.263 \\
\hline \multicolumn{7}{|l|}{ Brine } \\
\hline X6 & 0.030 & 0.029 & $<0.001$ & I & 0.290 & 0.290 \\
\hline $\mathrm{X} 7$ & 0.010 & 0.006 & 0.010 & 0.006 & 0.060 & 0.060 \\
\hline $\mathrm{X} 8$ & $<0.003$ & 0.006 & 0.010 & 0.006 & 0.060 & 0.057 \\
\hline X9 & 0.010 & 0.002 & 0.020 & 0.010 & 0.480 & 0.480 \\
\hline $\mathrm{X} 10$ & $<0.003$ & 0.006 & $<0.001$ & I & 0.150 & 0.150 \\
\hline
\end{tabular}

Table III. Exposure daily intake (EDI).

\begin{tabular}{lccc}
\hline Canned tuna & Pb EDI & Cd EDI & Hg EDI \\
\hline Olive oil & & & \\
X1 & - & 0.103 & 0.411 \\
X2 & - & 0.034 & 0.086 \\
X3 & 0.002 & 0.051 & 0.086 \\
X4 & 0.002 & 0.017 & 0.291 \\
X5 & - & 0.005 & 0.446 \\
Brine & & & \\
X6 & - & 0.051 & 0.497 \\
X7 & 0.002 & 0.017 & 0.103 \\
X8 & 0.002 & 0.005 & 0.103 \\
X9 & 0.017 & 0.017 & 0.823 \\
X10 & - & 0.005 & 0.257 \\
EPA-RDo $\mu$ g/kg-day & $/$ & 1 & $0.1^{\mathrm{a}}$ \\
WHO-PTDI & 3.57 & 0.833 & 0.571 \\
\hline
\end{tabular}

${ }^{a}$ EPA RDo for total mercury is not given, thus we considered that for methylmercury. Italicized text, THQ values above PTDI suggested by WHO.

limit $(0.30 \mathrm{mg} / \mathrm{kg}$ w.w.), moreover, in 5 brands (X1, X2, X5, $\mathrm{X} 6$ and $\mathrm{X9}) \mathrm{Pb}$ was found below the method detection limit. Regarding $\mathrm{Hg}$, all the analyzed brands had $\mathrm{Hg}$ concentrations below the law limit $(1.0 \mathrm{mg} / \mathrm{kg}$ w.w.), with a large range of concentrations, from 0.02 to $0.71 \mathrm{mg} / \mathrm{kg}$ w.w.), and highest values in canned tuna in brine X6 and X9 (Table II).

Mann-Whitney $\mathrm{U}$ test did not highlight any significant differences in metal concentrations between canned tuna in olive oil and canned tuna in brine. Conversely, the comparison between species revealed significantly higher concentrations of $\mathrm{Cd}(\mathrm{p}=0.001)$ in Katsuwonus pelamis than in Thunnus albacares (Fig. 2). The brand X9 to which belongs an undeclared species as well as an unidentified one was not included in this statistical test, but, as it can be seen in Table II, it has the highest value of $\mathrm{Hg}$.

Exposure to daily intake, calculated supposing a meal size corresponding to a full package of canned tuna (120 g) revealed intake values for $\mathrm{Pb}$ and $\mathrm{Cd}$ significantly below the levels of risk for human consumption (Table III). The consumption of most of the brands analyzed, revealed high levels of $\mathrm{Hg}$ daily intake if compared with the RfD suggested by EPA for $\mathrm{CH}_{3} \mathrm{Hg}$, conversely, $\mathrm{Hg}$-EDI are very close to the threshold suggested by WHO for tHg.

Target Hazard Quotient (THQ) was calculated to evaluate the risk of chronic systemic effects due to the consumption of the chosen brands of canned tuna. Furthermore, we evaluated this health risk factor supposing a different exposure scenario. For each brand, we have calculated the THQ with three levels of exposure frequency. In detail, for seven, four and one meals per week (Table IV).

We found the THQ always below the level of risk (THQ <1) both for $\mathrm{Cd}$ and $\mathrm{Pb}$ in all analyzed brands. The oral exposure to $\mathrm{Hg}$ derived by the ingestion of canned tuna is high for most of the selected brands, even if, as said before, the concentrations found are not over the law limit. Supposing that $\mathrm{Hg}$ found is $100 \% \mathrm{CH}_{3} \mathrm{Hg}$, a level of exposure of one meal per week could be protective against the toxic effect of $\mathrm{CH}_{3} \mathrm{Hg}$ for all the brands. Higher exposure than one meal per week could be at risk with the consumptions of brands X1, X4, X5, X6, X9 and X10. Only the brands X2 and $\mathrm{X} 3$ have $\mathrm{Hg}$ concentrations so low that they could be consumed even 7 times a week. Conversely, performing the THQ calculation by using the PTDI given by WHO for tHg, we found value higher than 1 in the brand $\mathrm{X} 9$ for a level of exposure of seven meals per week. The other brands, with the exception of the $\mathrm{X} 2, \mathrm{X} 3, \mathrm{X} 7$ and $\mathrm{X} 8$, for the same level of exposure, have values close to 1 . 
Table IV. Target hazard quotient (THQ) calculated for $\mathrm{Cd}, \mathrm{Pb}$ and $\mathrm{Hg}$ with different levels of exposure frequency (EF) of sampled brands.

\begin{tabular}{|c|c|c|c|c|c|}
\hline Brands & EF day/week & THQ Cd & THQ Pb & THQ Hg & THQ Hg \\
\hline \multicolumn{6}{|c|}{ Olive oil } \\
\hline \multirow[t]{3}{*}{$\mathrm{X} 1$} & 7 & 0.102 & 1 & 4.114 & 0.721 \\
\hline & 4 & 0.058 & l & 2.344 & 0.411 \\
\hline & 1 & 0.014 & I & 0.586 & 0.103 \\
\hline \multirow[t]{3}{*}{$\mathrm{X} 2$} & 7 & 0.034 & I & 0.857 & 0.150 \\
\hline & 4 & 0.019 & I & 0.488 & 0.086 \\
\hline & 1 & 0.004 & 1 & 0.122 & 0.021 \\
\hline \multirow[t]{3}{*}{ X3 } & 7 & 0.051 & 0.0004 & 0.857 & 0.150 \\
\hline & 4 & 0.029 & 0.0002 & 0.488 & 0.086 \\
\hline & 1 & 0.007 & 0.0001 & 0.122 & 0.021 \\
\hline \multirow[t]{3}{*}{$\mathrm{X} 4$} & 7 & 0.017 & 0.0004 & 2.914 & 0.510 \\
\hline & 4 & 0.009 & 0.0002 & 1.660 & 0.291 \\
\hline & 1 & 0.002 & 0.0001 & 0.415 & 0.073 \\
\hline \multirow[t]{3}{*}{$\mathrm{X} 5$} & 7 & 0.005 & 1 & 4.457 & 0.781 \\
\hline & 4 & 0.002 & I & 2.539 & 0.445 \\
\hline & 1 & 0.001 & I & 0.634 & 0.111 \\
\hline \multicolumn{6}{|l|}{ Brine } \\
\hline \multirow[t]{3}{*}{ X6 } & 7 & 0.051 & I & 4.971 & 0.871 \\
\hline & 4 & 0.029 & I & 2.833 & 0.496 \\
\hline & 1 & 0.007 & I & 0.708 & 0.124 \\
\hline \multirow[t]{3}{*}{$\mathrm{X} 7$} & 7 & 0.017 & 0.0004 & 1.028 & 0.180 \\
\hline & 4 & 0.009 & 0.0002 & 0.586 & 0.103 \\
\hline & 1 & 0.002 & 0.0001 & 0.146 & 0.026 \\
\hline \multirow[t]{3}{*}{$\mathrm{X} 8$} & 7 & 0.005 & 0.0004 & 1.028 & 0.180 \\
\hline & 4 & 0.002 & 0.0002 & 0.586 & 0.103 \\
\hline & 1 & 0.001 & 0.0001 & 0.146 & 0.026 \\
\hline \multirow[t]{3}{*}{$\mathrm{X} 9$} & 7 & 0.017 & 0.0043 & 8.228 & 1.441 \\
\hline & 4 & 0.009 & 0.0024 & 4.689 & 0.821 \\
\hline & 1 & 0.002 & 0.0006 & 0.172 & 0.205 \\
\hline \multirow[t]{4}{*}{ X10 } & 7 & 0.005 & 1 & 2.571 & 0.450 \\
\hline & 4 & 0.002 & I & 1.465 & 0.257 \\
\hline & 1 & 0.007 & 1 & 0.366 & 0.064 \\
\hline & RfD or PTDI & $\mathrm{RfD}$ for $\mathrm{Cd}$ & PTDI for $\mathrm{Pb}$ and compounds & $\mathrm{RfD}$ for $\mathrm{CH}_{3} \mathrm{Hg}$ & PTDI for $\mathrm{tHg}$ \\
\hline
\end{tabular}

\section{Discussion}

The results obtained in this work deal with two main issues of food safety: the species authentication in transformed products, to unveil commercial frauds due to the substitutions of high value species with species of low commercial value, and the assessment of health risk to consumers related to the level of heavy metal contents in canned tuna in olive oil or in brine. The COI DNA barcode analysis revealed that nine out of ten of most popular commercial brands of tuna sold in Italy contain the species declared in the label, Thunnus albacares and Katsuwonis pelamis. Although appropriate species traceability and labeling is nowadays requested by laws, mislabeling is often difficult to demonstrate because more than one species is marketed under the same name.

The current list of trade names of fish species of commercial interest marketed in Italy (Italian Ministerial Decree - MD - of January 31, 2008 as further supplemented and amended by MD August 12, 2011 and December 23, 2010) includes ten tuna species. Three species (Euthynnus affinis, Euthynnus lineatus and Thunnus tonggol) are marketed as Indopacific tuna, while each of the remaining seven species are marketed under specific names and in particular these were yellowfin tuna for T. albacares and skipjack tuna for K. pelamis. These 
two species are the more common varieties used for preparation of canned tuna and the products studied by us were properly labeled. However, the canned tuna has high potential to be the target of intentional or unintentional mislabeling: for example striped bonito (Sarda orientalis) was found in products labeled as tongol tuna (Thunnus tonggol), a case of evident economic fraud (49). Studies by Lowenstein et al (50) uncovered pieces of tuna sushi to contain endangered species (protected under the Convention on International Trade in Endangered Species of Wild Fauna and Flora - CITES) such as the northern bluefin tuna (T. thynnus) and the southern bluefin tuna (T. maccoyii); they also found the escolar (Lepidocybium flavorunneum), banned for sale in Italy and Japan because it contains gempylotoxin causing digestive symptoms, sold as white tuna (T.albacore). The authentication of tuna species by DNA barcoding was also of paramount importance to relate the health risk to consumers to the content of heavy metals in tuna species (40).

Fish that is almost of the higher trophic level, such as tuna, would be considered unsafe for human consumption because to the bioaccumulation of contaminants up to the food chain. Heavy metals are known for their toxicity and because they can cause health risks in consumers through ingestion of contaminated foods (51). Although the outcomes of more recent monitoring studies have been different in that they stressed that the maximum levels set by regulations of the respective countries had been frequently exceeded, a food that exceeds the maximum food standard is not necessarily unfit for human consumption. Conversely, a food that does not exceed the maximum food standard could be unfit for human consumption: these limits are conservatively set for regulatory purpose and assume a worst-case scenario. For this reason it is important to evaluate the metal daily intake and the health risk during the lifetime, building different scenarios of food habits.

In the brands analyzed in this study, we found concentrations of $\mathrm{Cd}, \mathrm{Pb}$ and $\mathrm{Hg}$, almost within the limits set by the European Regulation, with the exception of one batch belonging to the brand X3, identified as $K$. pelamis. Overall, we did not find any significant differences in concentrations of metals between canned tuna processed in olive oil or in brine. K. pelamis was identified as the species with the highest $\mathrm{Cd}$ bioaccumulation values $(\mathrm{p}<0.01)$, with a mean value of 0.035 if compared with $T$. albacore where a mean value of $0.007 \mathrm{mg} / \mathrm{kg}$ was found. From a literature review, the concentrations of $\mathrm{Cd}$ we found, have comparable values to that of canned tuna distributed in other national and international markets (52-56).

Some markets in Iran, Nigeria and Kingdom of Saudi Arabia revealed $\mathrm{Cd}$ concentrations of canned tuna significantly higher than the regulation followed in the European countries $(57,58)$. In literature it is known that $\mathrm{Cd}$ is a very dangerous toxicant with adverse health effects after long-term oral exposure including kidney dysfunction, bone damage via oxidative stress (osteomalacia, osteoporosis, fractures) and nephrotoxicity (59). Moreover, it was classified as a human carcinogen, group I, by the International Agency for Research on Cancer (IARC) (60). Observed alterations of DNA, as consequences of $\mathrm{Cd}$ applications in experimental models of mammalian cell cultures, higher plants, and intact animals include decreased fidelity of DNA synthesis and DNA repair, gene mutations, and chromosomal abnormalities. However,
Cd does not appear to possess significant genotoxic potential via the oral route (61). The Environmental Protection Agency (EPA) and the World Health Organization (WHO) suggest similar value of maximum daily intake $(\mathrm{RfD}=0.1$ and $\mathrm{PTDI}=0.833 \mu \mathrm{g} / \mathrm{kg}$-day, respectively) unlikely to cause adverse health effects. Our results related to the Cd-EDI and Cd-THQ revealed daily intake values largely below the recommended doses for each brands as well as THQ below the level of risk, supposing a consumption of canned tuna from one to seven portions of $120 \mathrm{~g}$ per week.

Regarding to $\mathrm{Pb}$, concentrations found are unexpectedly lower than literature finding related to canned tuna $(52,54-$ 58). Pollution of $\mathrm{Pb}$ is an environmental and public health hazard for its persistence and toxicity. To date, the introduction of unleaded petrol has progressively reduced its spread. Children are more susceptible to $\mathrm{Pb}$ than adults due to higher gastrointestinal uptake and the permeable blood-brain barrier (62). This leads to behavioral disturbances, learning and concentration difficulties, and diminished intellectual capacity. The pathogenic effect of $\mathrm{Pb}$ is multifactorial because it directly interrupts the activity of enzymes, competitively inhibits absorption of important trace minerals, and deactivates antioxidant sulfhydryl pools (63). Besides its ability to induce brain disorders, $\mathrm{Pb}$ may also cause hypertension, kidney damage, anemia, and negative effects on fertility (64). $\mathrm{Pb}$ compounds also cause genetic damage by several indirect mechanisms, including inhibition of DNA synthesis and repair, oxidative damage, and interaction with DNA-binding proteins and tumor-suppressor proteins and increase in frequency of chromosomal aberrations (65). Inorganic $\mathrm{Pb}$ compounds are classified as probably carcinogenic to humans (group 2A) by IARC (66).

WHO suggests for $\mathrm{Pb}$ a maximum provisional daily intake of $3.57 \mu \mathrm{g} / \mathrm{kg}$-day, conversely EPA is reviewing the information, and RfD was not yet estimated. On the basis of concentrations found in the brands chosen for this study, surely, both the Pb-EDI and the Pb-THQ estimated are widely lower the level of risk.

Concentrations of $\mathrm{Hg}$ detected in our samples are of concern for human consumption, although below the threshold set by European regulation, as well as most of literature data on processed canned tuna around the world (52-54,67-70). It is recognized as the most deleterious pollutant with regard to both its effects on marine organisms and its potential hazard to humans. The most toxic chemical species of mercury is methylmercury, formed by bacterial methylation of inorganic mercury in aquatic sediment; it may cause permanent harm to the central nervous system, such as affecting normal neuronal development, behavioral disorders, and deficiencies in the immune systems (71). Prenatal life is more sensitive than adult life to the toxic effects of methylmercury. In the case of prenatal exposure, the effects of methylmercury seem to be quite different and of a much more general nature. It affects normal neuronal development, with altered brain architecture and decreased brain size.

Methylmercury may also exert an effect on cell division during critical stages in the formation of the central nervous system. Exposure to $\mathrm{Hg}$ in utero during pregnancy or in early childhood, in fact, is related to neurodevelopmental disorders such as dyslexia, attention deficit hyperactivity disorder, 
intellectual retardation, and autism (72). In adults, methylmercury has the potential to induce delayed neurotoxicity years after cessation of exposure or as a result of low-level exposure over a large portion of the life span (73). Its neurotoxicity includes symptoms such as excessive tremor, insomnia, fatigue, and various psychological disorders (64). The average daily intake of $\mathrm{Hg}$ from food is in the range of 2-20 $\mu \mathrm{g} \mathrm{(73),} \mathrm{and} \mathrm{seafood} \mathrm{is}$ recognized as the main source of methylmercury in the general population $(74,75)$. This is also an important point for the food chain, as mercury increases in the upper level, ending up in the diet of humans. Maximum provisional daily intake suggested by EPA and WHO and considered for this study are different because EPA provides only the reference dose for methylmercury $\left(\mathrm{CH}_{3} \mathrm{Hg}\right)(0.1 \mu \mathrm{g} / \mathrm{kg}$-day), instead WHO provides also the PTDI of total mercury $(0.571 \mu \mathrm{g} / \mathrm{kg}$-day $)$. Our results highlighted lower value of EDI if compared with PTDI, but higher values if compared with the RfD, assuming the total amount we found as methylmercury. THQ is also of great concern, and overall, we would suggest a consumption of canned tuna with no more than two meals per week.

Overall, in all tested samples commercial fraud related to the identification of declared species were not recognized. Furthermore, none of the products surpassed the European regulatory limits no. 1881/2006 fixed for $\mathrm{Hg}$ and $\mathrm{Pb}$, whereas one batch of canned tuna in olive oil exceeded standard for $\mathrm{Cd}$. However, the data obtained clearly indicated that mercury exposure to human could be minimized if the consumption of tuna is limited to one meal per week. In addition, risk reduction should include a better risk communication to allow the understanding of the relationship among $\mathrm{Hg}$ and fish size, fish species, and trophic levels, to reduce the consumption of the number of higher predatory meals.

\section{References}

1. Tomasello B, Copat C, Pulvirenti V, Ferrito V, Ferrante M, Renis M, Sciacca S and Tigano C: Biochemical and bioaccumulation approaches for investigating marine pollution using Mediterranean rainbow wrasse, Coris julis (Linneaus 1798). Ecotoxicol Environ Saf 86: 168-175, 2012.

2. Ferrante M, Copat C, Mauceri C, Grasso A, Schilirò T and Gilli G: The importance of indicators in monitoring water quality according to European directives. Epidemiol Prev 39 (Suppl 1): $71-75,2015$

3. D'Agata A, Fasulo S, Dallas LJ, Fisher AS, Maisano M, Readman JW and Jha AN: Enhanced toxicity of 'bulk' titanium dioxide compared to 'fresh' and 'aged' nano-TiO2 in marine mussels (Mytilus galloprovincialis). Nanotoxicology 8: 549-558, 2014

4. Longo G, Trovato M, Mazzei V, Ferrante M and Conti GO: Ligia italica (Isopoda, Oniscidea) as bioindicator of mercury pollution of marine rocky coasts. PLoS One 8: e58548, 2013.

5. Copat C, Arena G, Fiore M, Ledda C, Fallico R, Sciacca S and Ferrante M: Heavy metals concentrations in fish and shellfish from eastern Mediterranean Sea: Consumption advisories. Food Chem Toxicol 53: 33-37, 2013.

6. European Food Safety Authority: EFSA Strategy 2020: Trusted Science for Safe Food. EFSA, Parma, 2015. https://www.efsa. europa.eu/sites/default/files/151008.pdf.

7. Oliveri Conti G, Copat C, Wang Z, D'Agati P, Cristaldi A and Ferrante M: Determination of illegal antimicrobials in aquaculture feed and fish: An ELISA study. Food Control 50: 937-941, 2015.

8. Dadar M, Adel M, Ferrante M, Saravi N, Copat C and Oliveri Conti G: Potential risk assessment of trace metals accumulation in food, water and edible tissue of rainbow trout (Oncorhynchus mykiss) farmed in Haraz River, northern Iran. Toxin Rev 35: 141-146, 2016.
9. Copat C, Brundo MV, Arena G, Grasso A, Oliveri Conti G, Ledda C, Fallico R, Sciacca S and Ferrante M: Seasonal variation of bioaccumulation in Engraulis encrasicolus (Linneaus, 1758) and related biomarkers of exposure. Ecotoxicol Environ Saf 86: 31-37, 2012

10. Conte F, Copat C, Longo S, Conti GO, Grasso A, Arena G, Brundo MV and Ferrante M: First data on trace elements in Haliotis tuberculata (Linnaeus, 1758) from southern Italy: Safety issues. Food Chem Toxicol 81: 143-150, 2015

11. Conte F, Copat C, Longo S, Conti GO, Grasso A, Arena G, Dimartino A, Brundo MV and Ferrante M: Polycyclic aromatic hydrocarbons in Haliotis tuberculata (Linnaeus, 1758) (Mollusca, Gastropoda): Considerations on food safety and source investigation. Food Chem Toxicol 94: 57-63, 2016.

12. Ababneh F and Al-Momani I: Levels of mercury, cadmium, lead and other selected elements in canned tuna fish commercialised in Jordan. Int J Environ Anal Chem 93: 755-766, 2013.

13. Burger J and Gochfeld M: Mercury and selenium levels in 19 species of saltwater fish from New Jersey as a function of species, size, and season. Sci Total Environ 409: 1418-1429, 2011.

14. Storelli MM and Marcotrigiano GO: Content of mercury and cadmium in fish (Thunnus alalunga) and cephalopods (Eledone moschata) from the south-eastern Mediterranean Sea. Food Addit Contam 21: 1051-1056, 2004.

15. Teffer AK, Staudinger MD, Taylor DL and Juanes F: Trophic influences on mercury accumulation in top pelagic predators from offshore New England waters of the northwest Atlantic Ocean. Mar Environ Res 101: 124-134, 2014.

16. Jakimska A, Konieczka P, Skora $\mathrm{K}$ and Namiesnik J: Bioaccumulation of metals in tissue of marine animals, part II: Metal concentrations in animal tissues. Pol J Environ Stud 5: 1127-1146, 2011.

17. EFSA: Statement on the benefits of fish/seafood consumption compared to the risks of methylmercury in fish/seafood. EFSA J 13: 3982, 2015.

18. Garcia-Vazquez E, Perez J, Martinez JL, Pardiñas AF, Lopez B, Karaiskou N, Casa MF, Machado-Schiaffino G and Triantafyllidis A: High level of mislabeling in Spanish and Greek hake markets suggests the fraudulent introduction of African species. J Agric Food Chem 59: 475-480, 2011.

19. Changizi R, Farahmand H, Soltani M, Asareh R and Ghiasvand Z: Species identification reveals mislabeling of important fish products in Iran by DNA barcoding. Iran J Fish Sci 12: 783-791, 2013. http://jifro.ir/article-1-1338-en.pdf.

20. Helyar SJ, Lloyd HA, de Bruyn M, Leake J, Bennett N and Carvalho GR: Fish product mislabelling: Failings of traceability in the production chain and implications for illegal, unreported and unregulated (IUU) fishing. PLoS One 9: e98691, 2014.

21. Huang YR, Yin MC, Hsieh YL, Yeh YH, Yang YC, Chung YL and Hsieh $\mathrm{CH}$ : Authentication of consumer fraud in Taiwanese fish products by molecular trace evidence and forensically informative nucleotide sequencing. Food Res Int 55: 294-302, 2014.

22. Armani A, Guardone L, Castigliego L, D'Amico P, Messina A, Malandra R, Gianfaldoni D and Guidi A: DNA and Mini-DNA barcoding for the identification of Porgies species (family Sparidae) of commercial interest on the international market. Food Control 50: 589-596, 2015.

23. Bénard-Capelle J, Guillonneau V, Nouvian C, Fournier N, Le Loët K and Dettai A: Fish mislabelling in France: Substitution rates and retail types. PeerJ 2: e714, 2015.

24. Lamendin R, Millen K and Ward R: Labelling accuracy in Tasmanian seafood: An investigation using of DNA barcoding. Food Control 47: 436-443, 2015.

25. Galimberti A, De Mattia F, Losa A, Bruni I, Federici S, Casiraghi M, Martellos S and Labra M: DNA barcoding as a new tool for food traceability. Food Res Int 50: 55-63, 2013.

26. Hebert PD, Cywinska A, Ball SL and deWaard JR: Biological identifications through DNA barcodes. Proc Biol Sci 270: 313-321, 2003.

27. Hebert PD, Ratnasingham S and deWaard JR: Barcoding animal life: Cytochrome c oxidase subunit 1 divergences among closely related species. Proc Biol Sci 270 (Suppl 1): S96-S99, 2003.

28. Hebert PD, Stoeckle MY, Zemlak TS and Francis CM: Identification of birds through DNA barcodes. PLoS Biol 2: e312, 2004.

29. Hajibabaei M, Smith MA, Janzen DH, Rodriguez JJ, Whitfield JB and Hebert PD: A minimalist barcode can identify a specimen whose DNA is degraded. Mol Ecol Notes 6: 959-964, 2006. 
30. Pappalardo A and Ferrito V: A COIBar-RFLP strategy for the rapid detection of Engraulis encrasicolus in processed anchovy products. Food Control 57: 385-392, 2015.

31. Pappalardo AM, Guarino F, Reina S, Messina A and De Pinto V: Geographically widespread swordfish barcode stock identification: A case study of its application. PLoS One 6: e25516, 2011.

32. Pappalardo AM, Federico C, Sabella G, Saccone S and Ferrito V: A COI nonsynonymous mutation as diagnostic tool for intraspecific discrimination in the European anchovy Engraulis encrasicolus (Linnaeus). PLoS One 10: e0143297, 2015.

33. Pappalardo A and Ferrito V: DNA barcoding species identification unveils mislabeling of processed flatfish products in southern Italy markets. Fish Res 164: 153-158, 2015.

34. Ferrito V, Bertolino V and Pappalardo A: White fish authentication by COIBar-RFLP: Toward a common strategy for the rapid identification of species in convenience seafood. Food Control 70: 130-137, 2016.

35. Ward RD, Zemlak TS, Innes BH, Last PR and Hebert PD: DNA barcoding Australia's fish species. Philos Trans R Soc Lond B Biol Sci 360: 1847-1857, 2005.

36. Lefébure T, Douady CJ, Gouy M and Gibert J: Relationship between morphological taxonomy and molecular divergence within Crustacea: Proposal of a molecular threshold to help species delimitation. Mol Phylogenet Evol 40: 435-447, 2006.

37. Ogden R: Fisheries forensics: The use of DNA tools for improving compliance, traceability and enforcement in the fishing industry. Fish Fish 9: 462-472, 2008.

38. Dawnay N, Ogden R, McEwing R, Carvalho GR and Thorpe RS: Validation of the barcoding gene COI for use in forensic genetic species identification. Forensic Sci Int 173: 1-6, 2007.

39. Pappalardo A, Cuttitta A, Sardella A, Musco M, Maggio T, Patti B, Mazzola S and Ferrito V: DNA barcoding and COI sequence variation in Mediterranean lanternfishes larvae. Hydrobiologia 749: 155-167, 2015.

40. Lowenstein JH, Burger J, Jeitner CW, Amato G, Kolokotronis SO and Gochfeld M: DNA barcodes reveal species-specific mercury levels in tuna sushi that pose a health risk to consumers. Biol Lett 6: 692-695, 2010.

41. Hall TA: BioEdit: A user-friendly biological sequence editor and analysis program for Windows 95/08/NT. Nucleic Avids Symp Ser 41: 95-98 1999.

42. Thompson JD, Gibson TJ, Plewniak F, Jeanmougin F and Higgins DG: The CLUSTAL_X windows interface: Flexible strategies for multiple sequence alignment aided by quality analysis tools. Nucleic Acids Res 25: 4876-4882, 1997.

43. Tamura K, Peterson D, Peterson N, Stecher G, Nei M and Kumar S: MEGA5: Molecular evolutionary genetics analysis using maximum likelihood, evolutionary distance, and maximum parsimony methods. Mol Biol Evol 28: 2731-2739, 2011.

44. Felsenstein J: Confidence limits on phylogenies: An approach using the bootstrap. Evolution 39: 783-791, 1985.

45. Adel M, Oliveri Conti G, Dadar M, Mahjoub M, Copat C and Ferrante M: Heavy metal concentrations in edible muscle of whitecheek shark, Carcharhinus dussumieri (elasmobranchii, chondrichthyes) from the Persian Gulf: A food safety issue. Food Chem Toxicol 97: 135-140, 2016.

46. Copat C, Bella F, Castaing M, Fallico R, Sciacca S and Ferrante M: Heavy metals concentrations in fish from Sicily (Mediterranean Sea) and evaluation of possible health risks to consumers. Bull Environ Contam Toxicol 88: 78-83, 2012.

47. Conti GO, Copat C, Ledda C, Fiore M, Fallico R, Sciacca S and Ferrante M: Evaluation of heavy metals and polycyclic aromatic hydrocarbons (PAHs) in Mullus barbatus from Sicily Channel and risk-based consumption limits. Bull Environ Contam Toxicol 88: 946-950, 2012.

48. Zhang DX and Hewitt GM: Nuclear integrations: Challenges for mitochondrial DNA markers. Trends Ecol Evol 11: 247-251, 1996.

49. Mitchell JK and Hellberg RS: Use of the mitochondrial control region as a potential DNA mini-barcoding target for the identification of canned tuna species. Food Anal Methods 9: 2711-2720, 2016.

50. Lowenstein JH, Amato G and Kolokotronis SO: The real maccoyii: Identifying tuna sushi with DNA barcodes - contrasting characteristic attributes and genetic distances. PLoS One 4: e7866, 2009.

51. Bosch AC, O'Neill B, Sigge GO, Kerwath SE and Hoffman LC: Heavy metals in marine fish meat and consumer health: A review. J Sci Food Agric 96: 32-48, 2016.
52. Okyere H, Voegborlo RB and Agorku SE: Human exposure to mercury, lead and cadmium through consumption of canned mackerel, tuna, pilchard and sardine. Food Chem 179: 331-335, 2015.

53. Storelli MM, Barone G, Cuttone G, Giungato D and Garofalo R: Occurrence of toxic metals $(\mathrm{Hg}, \mathrm{Cd}$ and $\mathrm{Pb})$ in fresh and canned tuna: Public health implications. Food Chem Toxicol 48: 3167-3170, 2010.

54. Russo R, Lo Voi A, De Simone A, Serpe FP, Anastasio A, Pepe T, Cacace D and Severino L: Heavy metals in canned tuna from Italian markets. J Food Prot 76: 355-359, 2013.

55. Andayesh S, Hadiani MR, Mousavi Z and Shoeibi S: Lead, cadmium, arsenic and mercury in canned tuna fish marketed in Tehran, Iran. Food Addit Contam Part B Surveill 8: 93-98, 2015.

56. Morshdy AE, Hafez AE, Darwish WS, Hussein MA and Tharwat AE: Heavy metal residues in canned fishes in Egypt. Jpn J Vet Res 61 (Suppl): S54-S57, 2013.

57. Hosseini SV, Sobhanardakani S, Miandare HK, Harsij M and Regenstein JM: Determination of toxic $(\mathrm{Pb}, \mathrm{Cd})$ and essential $(\mathrm{Zn}, \mathrm{Mn}$ ) metals in canned tuna fish produced in Iran. J Environ Health Sci Eng 13: 59, 2015.

58. Iwegbue CM: Metal concentrations in selected brands of canned fish in Nigeria: Estimation of dietary intakes and target hazard quotients. Environ Monit Assess 187: 85, 2015

59. Sabath E and Robles-Osorio ML: Renal health and the environment: Heavy metal nephrotoxicity. Nefrologia 32: 279-286, 2012.

60. IARC: Beryllium, cadmium, mercury and exposure in the glass manufacturing industry. In: Cadmium and Cadmium Compounds. Vol. 58. WHO Press, Lyon, pp119-237, 1993.

61. World Health Organization: Background document for development of WHO guidelines for drinking-water quality. In: Cadmium in Drinking Water. WHO Press, Geneva, 2011.

62. Järup L: Hazards of heavy metal contamination. Br Med Bull 68: $167-182,2003$.

63. Jomova $\mathrm{K}$ and Valko $\mathrm{M}$ : Advances in metal-induced oxidative stress and human disease. Toxicology 283: 65-87, 2011.

64. Kakkar P and Jaffery FN: Biological markers for metal toxicity. Environ Toxicol Pharmacol 19: 335-349, 2005.

65. National Toxicology Program, U.S. Department of Health and Human Services: Report on Carcinogens (RoC). 12th edition, 2011. http://ntp.niehs.nih.gov/ntp/roc/twelfth/roc12.pdf.

66. International Agency for Research on Cancer (IARC): IARC Monographs on the Evaluation of Carcinogenic Risks to Humans: Inorganic and Organic Lead Compounds. Vol. 87. WHO Press, Lyon, 2006.

67. Burger $\mathbf{J}$ and Gochfeld M: Mercury in fish available in supermarkets in Illinois: Are there regional differences. Sci Total Environ 367: 1010-1016, 2006.

68. Ruelas-Inzunza J, Patiño-Mejía C, Soto-Jiménez M, BarbaQuintero G and Spanopoulos-Hernández M: Total mercury in canned yellowfin tuna Thunnus albacares marketed in northwest Mexico. Food Chem Toxicol 49: 3070-3073, 2011.

69. Dabeka RW, Mckenzie AD and Forsyth DS: Total mercury in canned tuna sold in Canada in 2006. Food Addit Contam Part B Surveill 7: 110-114, 2014.

70. García MÁ, Núñez R, Alonso J and Melgar MJ: Total mercury in fresh and processed tuna marketed in Galicia (NW Spain) in relation to dietary exposure. Environ Sci Pollut Res Int 23: 24960-24969, 2016.

71. United Nations Environment Programme: Global Mercury Assessment. UNEP Chemicals, Geneva, 2002.

72. Weiss B: Vulnerability of children and the developing brain to neurotoxic hazards. Environ Health Perspect 108 (Suppl 3): 375-381, 2000

73. World Health Organization: Background document for development of WHO guidelines for drinking-water quality. In: Mercury in Drinking-Water. WHO Press, Geneva, 2005.

74. Storelli MM, Giacominelli-Stuffler R and Marcotrigiano GO: Relationship between total mercury concentration and fish size in two pelagic fish species: Implications for consumer health. J Food Prot 69: 1402-1405, 2006.

75. Copat C, Vinceti M, D'Agati MG, Arena G, Mauceri V, Grasso A, Fallico R, Sciacca S and Ferrante M: Mercury and selenium intake by seafood from the Ionian Sea: A risk evaluation. Ecotoxicol Environ Saf 100: 87-92, 2014. 